\title{
THE EVALUATION OF DEMOGRAPHIC FEATURES AND HISTOPATHOLOGICAL RESULTS IN PATIENTS WITH REOPERATIVE E THYROID SURGERY
}

\section{Neslihan CUHACI ${ }^{1}$, Husniye BASER ${ }^{2}$, Cevdet AYDIN¹. Aylin KILIC YAZGAN³ . Seyda TURKOLMEZ4, Mehmet KILIC ${ }^{5}$, Reyhan ERSOY', Bekir CAKIR ${ }^{1}$}

Yildirim Beyazit University, Faculty of Medicine, Ataturk Education and Research Hospital, Department of Endocrinology and Metabolism, Ankara, TURKEY

${ }^{2}$ Ataturk Education and Research Hosital, Department of Endocrinology and Metabolism, Ankara, TURKEY

${ }^{3}$ Ataturk Education and Research Hospital, Department of Pathology, ANKARA, TURKEY

${ }^{4}$ Yildiiım Beyazit University, Faculty of Medicine, Ataturk Education and Research Hospital, Department of Nuclear Medicine, ANKARA, TURKEY ${ }^{5}$ Yildirim Beyazit University, Faculty of Medicine, Ataturk Education and Research Hospital, Department of General Surgery, ANKARA, TURKEY

\section{INTRODUCTION}

$>$ Reoperative surgery for thyroid disease is indicated in case of recurrent uni or multinodular goiter when there is compression or in the suspicion of malignancy and in some cases of recürrent thyrotoxicosis.

$>$ Reoperative thyroid surgery is associated with increased morbidity due to scar tissue which makes it more difficult to avoid injury to the recurrent laryngeal nerve (RLN) or the vascular pedicle of the parathyroid gland. Although fineneedle aspiration cytology (FNAC) is simple, safe and noninvazive, it can lead to conflicting results in the reopeted patients for thyroid disease.

> Studies have already documented a significantly higher morbidity rate in reoperative thyroid surgery compared with initial surgery.

$>$ We aimed to investigate the demographic features and operation indications in re-operated patients for thyroid

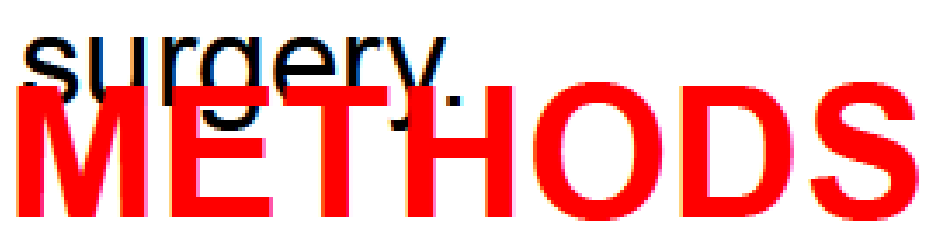

$>$ Thirty-six patients reoperated for thyroid surgery between 2008 - 2011 were included into the study. Demographic features, indications of reoperation and histopathological results of patients were evaluated retrospectively.

\section{RESULTS}

$>$ After reoperative thyroidectomy, the results of histopathological evaluation of 24 patients were malignant (19 papillary thyroid carcinomas, 3 follicular thyroid carcinomas, 1 Hurthle cell neoplasm and 1 neoplasm with undetermined malignant potential) while 12 patients were benign. Operation indications and the histopathological results were shown in the table.

$>$ Nodules with malignant histopathology, $45.5 \%$ had microcalcifications, $40.9 \%$ had macrocalcifications.
Table. Reoperation indications and histopathological results of the patients

\begin{tabular}{|c|c|c|}
\hline & $\begin{array}{l}\text { Malignant } \\
\quad(n=24)\end{array}$ & $\begin{array}{c}\text { Benign } \\
(n=12)\end{array}$ \\
\hline Giant nodule & 5 & 6 \\
\hline Toxic multinodular goitre & 1 & 2 \\
\hline \multicolumn{3}{|l|}{ CYTOLOGY } \\
\hline $\begin{array}{l}\text { Cellular adenomatoid } \\
\text { nodule }\end{array}$ & 2 & 1 \\
\hline Malignant & 5 & \\
\hline $\begin{array}{l}\text { Suspicious for } \\
\text { malignancy }\end{array}$ & 2 & \\
\hline $\begin{array}{l}\text { Suspicious for follicular } \\
\text { neoplasm }\end{array}$ & 2 & \\
\hline $\begin{array}{l}\text { Suspicious for Hurthle } \\
\text { cell neoplasm }\end{array}$ & 1 & \\
\hline $\begin{array}{l}\text { Atypia of undetermined } \\
\text { significance }\end{array}$ & 1 & \\
\hline $\begin{array}{l}\text { Follicular lesion of } \\
\text { undetermined } \\
\text { significance }\end{array}$ & 2 & 1 \\
\hline $\begin{array}{l}\geq 2 \text { Non-diagnostic } \\
\text { cytology }\end{array}$ & 3 & 2 \\
\hline
\end{tabular}

\section{CONCLUSION}

Thyroid surgery may lead to regional scars and some degree of fibrotic process. This may result in problems in collecting thyroid FNAC samples and assessing cellular abnormalities.

$>$ Our study findings demonstrated that histopathological evaluation of 14 patients whose cytological results showed no malignancy, was consistent with malignancy.

$>$ Therefore, we think it is crucial that in these group of patients operation indication is not only carry out with the FNAC results but also patients symptomps and ultrasonographic features must take into consideration. 